\title{
environmental
}

\section{politics and policy}

in the west

$T H \& R D$ D I T ION

Epited by Zachary A. Smith and John Freemuth 


\section{Contents}

Preface

Zachary A. Smith and John Freemuth vii

I. Energy, the Environment, and the American West: A

Policymaking Perspective

Leslie R. Alm 3

2. Bureaucracy and Politics of Energy and Environmental Policy in the Western States

Matthew A. Cahn, Sheldon Kamieniecki, Denise McCain-Tharnstrom, and Duran Fiack 27

3. Governance, Science, and the Federal Lands

John Freemuth and Esther Babcock 55 
4. Urban Planning and Environmental Policy in the West Hugh Bartling, Matt Lindstrom, and Ashleigh Walter 79

5. Renewable Energy Policymaking in the American West Charles Davis, Sandra Davis, and Cassandra Koerner 101

6. Water in the Western United States: Storied Past and Troubled Future Zachary A. Smith 127

7. The Politics of River Restoration

Daniel McCool 149

8. Wildlife Conservation Policy and Energy Deyelopment in Western States

William R. Mangun and Jean C. Mangun

9. Tribal Sovereignty: The Struggle to Balance Traditions of Environmental Stewardship with Modern-Era Energy Resource Development

Robert E. Forbis Jr. and Megan M. DeMasters 197

List of Contributors

Index 223 


\title{
I
}

\section{Energy, the Environment, and the American West}

\author{
A Policymaking Perspective
}

Leslie R. Alm

Public policymaking in the American West, especially as it concerns the natural environment, is a process sometimes viewed as "messy, foolish, erratic, and inexplicable" (Stone 20I2, Io). First there is the complexity (sometimes viewed as extreme complexity) of the policymaking process in general, where "problems are conceptualized and brought to government for solution; governmental institutions formulate alternatives and select policy solutions; and those solutions get implemented, evaluated, and revised" (Sabatier 2007, 3). Moreover, decisions made under the auspices of public policymaking are rarely permanent and very much representative of a fluid, dynamic, and malleable process (Gerston 2008) - a process said to be inclusive of all political activities and institutions, "from voting, political cultures, parties, legislatures, bureaucracies, international agencies, local governments, and back again to the citizens who implement and evaluate public policies” (John 2003, 483).

When one adds environmental and energy issues to this public policy mix, things become even more entangled, especially with today's renewed sense 
of urgency about climate change, energy independence, and resource management (Vig and Kraft 20I3) - all necessitating increasingly specialized competence to regulate sophisticated information, analysis, and advice (Kettle 2012). Environmental and energy politics means conflicts between value systems: conservation versus preservation, natural resources development versus environmental protection, individual property rights versus the government's right of eminent domain, and command and control regulatory systems versus market-oriented approaches. Such a combination makes for difficult reading and difficult analysis. Three decades past but still relevant today, Dean Mann — a highly respected environmental scholar-expressed the frustrations of dealing with such policymaking: "Environmental policy is not an artifact of administrations, grandly enunciated by presidents, duly enacted by responsive legislatures, and efficiently administered by the executive establishment. It is . . a jerry-built structure in which innumerable individuals, private groups, bureaucrats, politicians, agencies, courts, political parties, and circumstances have laid down the plans, hammered the nails, plastered over the cracks, made sometimes unsightly additions and deletions, and generally defied 'holistic' or 'ecological principles of policy design" (Mann I986, 4).

Within this context I will add one final ingredient-the American West. The imagery and reality of the American West is undauntedly clear and contradictory. On the one hand, there is the majestic beauty of the mountains, deserts, and wilderness areas. On the other hand, there is the spirited and often fierce battle gver the rights to scarce natural resources, be it the never-ending search for usable water or the renewed effort to find energy sources in a quest for energy stability and independence. The West also presents a sharply defined contrast between the vast open spaces that define a majority of rural counties and a booming growth in urban population centers where most of its citizens reside. To top it all off, the frontier ethos of rugged individualism characterized by intense anti-government attitudes comes into direct conflict with the dominance of, and reliance on, the federal government. These special characteristics make the West unique in the sphere of environmental policymaking. To study environmental policymaking in the United States is one thing. To study environmental policymaking in the American West - whether it deals with energy or the environment-is distinctive in important and interesting ways. As Walter Baber and Robert 
Bartlett make clear, to effectively understand the role the environment plays in our cultural experience, one requires a "wisdom of place" (2009, 19). The following sections delineate environmental and energy policymaking in the context of such a "place"- the American West.

The following sections focus specifically on providing a general policy framework from which readers can elicit large, philosophical interpretations of current issues dealing with both energy and environmental policymaking unique to the American West (depicted in the substantive chapters of this book) as this particular region of the United States struggles to maintain its relevance to American public policymaking in general. Within this policy framework, energy is viewed as a component of environmental policymaking, and what follows is an overview of the policymaking process as it pertains to the special qualities that characterize the American West while it deals with maintaining energy independence and environmental protection.

\section{Overview of the Policy Process}

To comprehend western environmental and energy policymaking, it is necessary to have a basic understanding of the oyerall policymaking process.

\section{Definition of Public Policy}

Because the study of public policy is a fairly recent phenomenon of political science, we are still struggling to grasp the essence of exactly what it entails. In fact, it is a common technique to begin books about public policy by simply asking the question, what is public policy? Michael Kraft and Scott Furlong, in their recently published public policy text, provide a concise, straightforward definition: "Public policy is a course of government action or inaction in response to public problems" (2013,4). They go on to explain that making public policy involves an attempt by government to address society's problems and that policy is a course of action, not just an isolated, onetime government act.

This line of thought—centered on the idea that the making of public policy involves the government attempting to deal with society's problems-is worth remembering, as it defines the very essence of public policymaking in the United States, including the American West. Furthermore, viewed in this 
light, the study of public policy is firmly grounded in the study of how political communities struggle with ideas (Stone 2012). More to the point, public policymaking is cast as "a constant struggle over the criteria for classification, the boundaries of categories, and the definition of ideals that guide the way people behave" (ibid., I3). In the end, it should always be remembered that "policies are not simply the random and chaotic product of a political process ... [They] have underlying patterns and logic, and the ideas included in policies have real consequences" (Schneider and Ingram 1997, 3). It is within this context that I will view the public policy process.

\section{Analysis of Public Policy}

One helpful way to visualize the policymaking process is to set up a specific framework of analysis. Fortunately, several good frameworks exist today.

While there is a wide array of frameworks, from those grounded in historicgeographic and socioeconomic conditions (Hofferbert 1974) to those that emphasize individual actors and their preferences, interests, and resources (Kiser and Ostrom 1982), the most common framework has been to represent the policymaking process as a sequence of linearly connected stages (Bonser, McGregor, and Oster 2000; Cochran et al. 2003).

Policymaking is seen as beginning in the agenda-setting stage, where issues are recognized as both worthy of governmental attention and within the legitimate scope of governmental action. From there the issue moves to the policy formulation stage, where a plan is developed to deal with it. In the next stage, policy adoption, a specific alternative or solution is chosen. Execution of the policy is then completed in the implementation stage, where policymakers use a variety of policy instruments to ensure their goals are achieved. After a period of time, a judgment is made regarding the success of implementation. This takes place in the evaluation stage. Finally, a determination is made as to whether the chosen plan of attack should be terminated, continued, or changed.

An offshoot of this policy-made-in-stages approach is based on the systems approach developed by David Easton (Robertson and Judd 1989). According to this approach, society makes demands on the government, the government reacts to these demands, and specific policies are formulated to meet the demands. The societal demands involve specific types of political behavior, 
TABLE I.I. Public policymaking frameworks

\begin{tabular}{|c|c|}
\hline Approach & Descriptives \\
\hline Stages & Agenda setting; formulation; adoption; implementation; evaluation \\
\hline Systems & Societal demands; government reaction; policy outcomes \\
\hline Multiple streams & $\begin{array}{l}\text { Problem, policy, political streams; windows of opportunity; focus- } \\
\text { ing events }\end{array}$ \\
\hline Advocacy coalitions & Groups with shared beliefs, common values \\
\hline Punctuated equilibrium & Dramatic reversals rather than marginal revisions \\
\hline Rational choice & Collective-choice rules; commitment to collective benefits \\
\hline Networks & Diversity of actors; mutual interdependence \\
\hline Social construction & Manipulation: reputation; image; social standing \\
\hline
\end{tabular}

political culture, and ideology. Moreover, these demands are passed forward through such mechanisms as public opinion, interest groups, mass media, political parties, and community elites. The government policymaking structure is set up to view and deal with these demands within an institutional structure consisting of legislatures, elected executives, courts, and bureaucracy (including administrative agencies).

Essentially, the government processes the demands to produce public policy. The end results are called policy outcomes and consist of laws, executive orders, court rulings, regulations, enforcement actions, budgets, and taxes. This type of approach focuses specifically on institutions and political behavior both inside and outside those institutions.

While this focus on institutions and political behavior has remained a very popular approach, there has been some criticism that viewing public policymaking through a simple sequence of stages is not sufficient to grasp the true meaning and development of public policy. In other words, the policymaking process may be viewed as much too complex to be explained in such a straightforward manner (John 2003). There now exist a number of relatively new theoretical frameworks of the policy process that are currently recognized as some of the most advanced approaches to the study of public policy and are directly relevant to our study of environmental and energy policymaking in the American West. Paul Sabatier (2007), in his second edition of Theories of the Policy Process, provides a listing of these frameworks, including multiple streams, advocacy coalitions, punctuated equilibrium, institutional rational choice, networks, and social construction. Each of these conceptual 
frameworks attempts to explain the American public policymaking process using a particular construct in a way that emphasizes how policy changes over time.

The multiple streams approach conceptualizes policymaking around enterprising policy entrepreneurs who make things happen within the context of three dynamic streams (problem, policy, and political) that merge at certain points in time (windows of opportunity) to stimulate the production of a specific public policy (Kingdon 20Ir; Zahariadis 2007). The problem stream consists of various mechanisms that bring problems to the attention of decision makers. One such mechanism is the focusing event, which includes disasters, crises, personal experiences, and symbols. However, focusing events need to be understood within the context of preexisting perceptions, especially about past governmental actions. It is important to note that government officials do not address all problems. Hence, the way problems are defined and under what conditions help determine their status in the problem stream.

The advocacy-coalition approach centers on advocacy coalitions-defined as groups of actors from both private and public organizations at all levels of government who share a common set of values or beliefs-as the primary determinants of public policy (Sabatier and Jenkins-Smith 1993; Sabatier and Weible 2007). The policy process is viewed within a framework in which these advocacy coalitions attempt to manipulate the rules of government to bring about change that coincides with their beliefs. This activity takes place within the basic social structure and in accordance with the constitutional rules of the system.

The punctuated-equilibrium approach, founded within the agenda-setting process, is structured around the principle that political systems are never in general equilibrium (Baumgartner and Jones 1993; True, Jones, and Baumgartner 2007). Frank Baumgartner and Bryan Jones depict the policy consequences of agenda setting as dramatic reversals rather than marginal revisions to the status quo. The generation of new ideas is viewed as creating an atmosphere such that policy monopolies (defined as structural arrangements supported by powerful ideas) are unstable over time. Policy is made with fits and starts, slow, then rapid, rather than in a linear, smooth way. Existing political institutions and issue definitions are viewed as key to the policymaking process, with issue definition, because of its potential for 
mobilizing the disinterested, seen as the driving force in that process, affecting both stability and instability.

The institutional rational choice approach is founded within political economy and rational choice theory, portraying policy within a framework where decision makers repeatedly have to make decisions constrained by a set of collective-choice rules (Ostrom 1990, 1999, 2007). Decisions are made based on incomplete knowledge, with policymakers gaining a greater understanding of their situations (and adopting their strategies) by learning from their mistakes. Elinor Ostrom's approach is designed to "shatter the convictions of many policy analysts that the only way to solve [common-pool resource] problems is for external authorities to impose full property rights or centralized regulation" (I990, I82). Through her critique of three conventional approaches (privatization, central regulation, and management by interested parties), Ostrom offers a picture of policymaking in which communities voluntarily develop policy rules, a commitment to collective benefits, and successful mutual monitoring (Weschler 199i).

The network approach is based on one of the central concepts of interorganizational theory-that actors are dependent on each other because they need each other's resources to achieve their goals - and on interest group and agenda-setting research whereby policy networks constitute a new form of governance characterized by the predominance of informal, decentralized, and horizontal relations (Adam and Kriesi 2007). Inherent in its tenets are that governmental organizations are no longer the steering actors in the policy process. Instead, there exists a diversity of actors who are mutually interdependent. Moreover, the interactions of these interdependent actors determine the form of policy change and the eventual outcomes.

The social construction approach attempts to explain a number of enduring dilemmas in a democratic polity that other frameworks do not adequately address. Helen Ingram, Anne Schneider, and Peter de Leon (2007) argue that policy design is recognized as having consequences where reputation, image, and social standing directly affect the notion of government and whether people choose to participate in the policy process. This approach centers on the power and influence of manipulation of such social constructions. Policymakers are viewed as responsive to such manipulations, with policy outcomes dependent on how well competing constructions are accepted. Policymaking is dynamic-there are no uniform social constructions. In 
essence, the ultimate policy design is based on persuading others that a particular way of framing an issue is the best way to approach creating a meaningful policy choice.

These approaches to the study of public policymaking vary, from looking at public policy as a linear process that takes place in definable stages, to the notion that it is the complex interaction of policy streams or policy subsystems that determines where we are going, to the notion that viable policy solutions exist outside mainstream approaches such as privatization and centralized government. While these conceptualizations are significant to the study of public policy, it still remains helpful to understand that the core of policymaking lies in behavior that takes place within our policy institutions (legislatures, the presidency, courts, interest groups, administrative agencies, local governments, and political parties) and in behavior that takes place outside these political institutions (public opinion, voting, political culture, and political socialization).

\section{American Public Policy}

Public policy in the United States is not made in a vacuum: "It is affected by social and economic conditions, prevailing political values and the public mood at any given time, the structure of government, and national and local cultural norms" (Kraft and Furlong 2013, 8). Moreover, as described, the American public policymaking process is extremely intricate and complex, highly competitive, fragmented, and specialized (Milakovich and Gordon 2013). Within this context, Larry Gerston (2008)—as outlined below-lays out what he believes are the four uniquely special features of America's system of governance and policymaking: separation of powers, federalism, judicial review, and chartered rights.

Separation of powers means the sharing of authority, and the system of checks and balances ensures that each branch has some control over the others' powers. These shared powers are highlighted by a high degree of both fragmentation and incrementalism. Fragmentation underscores the redundancy and overlapping of authority between and among branches. For each issue, there is generally no central point of control, leading to inconsistent and fractured policymaking characterized by numerous points of access for interest groups to pursue their separate agendas. The incremental nature of American policymaking prevents dynamic and innovative changes except on 
rare occasions. Most policy is based on the current or previous policy, with only small, incremental changes.

American federalism-systems set up such that the national government shares power with the fifty states-has created a complex set of intergovernmental relations. Although each level's authority is set in constitutional law, the interpretation of that law has led to considerable competition among the levels to establish and retain authority. While our federal system is often cast in terms of cooperation and compromise among different levels of government, the reality is that one of the great tensions in American public policymaking today is caused by highly contentious relationships between states and the federal government. This is particularly prevalent in the American West, which has a long-standing and well-established antagonism toward the national level of government.

Judicial review-the power of the courts to determine the constitutionality of a legislative act - is founded on a commitment to constitutional government and ensures that all public policy in the United States complies with America's legal norms. Judicial review also represents the enormous importance of law in American life and establishes the legal profession as one of the dominant forces in US governance. It ensures that when a policy is made, it is made with the knowledge that it is not only subject to constitutional scrutiny but that it can beruled null and void by the courts.

Chartered rights are the individual rights delineated in the Bill of Rights and highlighted by the due process and equal protection clauses of the Fourteenth Amendment. These individual rights have come to be accepted as an essential feature of America's democratic system, a way to protect individual conscience, expressions, and privacy. Especially important in this regard are the provisions that states (I) cannot deprive citizens of life, liberty, or property without due process of law or (2) deny their citizens equal protection of the law. These individual rights help illuminate the dynamic role citizens' beliefs, convictions, and passions play in the public policymaking process.

In addition to these characteristics as defined by Gerston (2008), two divergent perspectives exist in the United States about who actually controls the power of governance: pluralism and elitism (Alm, Burkhart, and Simon 2010). The pluralistic view argues that policy is made within a system based on multiple and competing interests and groups vying for control over any given issue. Participation comes from being a member of those interests or groups. 
In the elite theory of governance, participation comes only from the few who possess special characteristics, such as wealth or institutional status.

Political stalemate appears to be a cause of considerable disruption in US policymaking, as is Americans' declining trust in government (Kettle 2012; McNabb 2009). However, a careful analysis of how American public policymaking works shows that the system was set up to be slow, deliberate, and often very confusing (Bosso 1987). It is a system based upon an inherent faith in democratic institutions and founded upon shared social, political, and cultural ideals. There is also a sharing of common problems. Urban decay, deteriorating infrastructure, increasing crime, environmental degradation, and energy independence are just some of the problems common to all regions of America today. In the end, policymakers must deal with all aspects of American life, both good and bad.

Overview of American Energy and Environmental Policymaking

The Energy-Environmental Interrelationship

There exists a complex interrelationship between energy and environmental protection policies. This relationship causes the government to be quite erratic in its policymaking, sometimes pushing market-type policies (e.g., coal, oil, natural gas, acid rain pollution) while at other times favoring government regulation (e.g., nuclear energy, hazardous waste disposal, air and water pollution). Still, whether one is referring to energy or environmental protection, the policy process delineated in detail earlier in this chapter applies. With that in mind, the following description of policymaking views both energy and environmental protection issues as falling under the rubric of environmental policymaking. In short, when referring to environmental policymaking in the United States (and in the American West), readers should understand that - for the purposes of this discussion-energy and environmental policymaking are considered under the same umbrella.

Environmental Policymaking: The Past and the Present

The modern environmental movement in the United States is said to have been ushered in between the publication of Rachel Carson's Silent Spring 
in 1962 and the first Earth Day celebration in I970 (Kline 20II), leading into a decade that brought the establishment of the Environmental Protection Agency and the Council on Environmental Quality and the passage of the Clean Air Act of 1970, the Clean Water Act of 1972, the Endangered Species Act of 1973, as well as a series of laws dealing with hazardous waste and toxic pollution-all designed to protect the natural environment.

However, this decade of activism and its emphasis on environmental protection is long gone. From the 1980s onward, we have witnessed either a backlash against environmentalism in general or a simple complacency regarding environmental protection. The Ronald Reagan and George W. Bush administrations were characterized by overt attempts to deregulate US policy as a whole and a general weakening of environmental regulations. The administrations of George H.W. Bush and Bill Clinton were marked by few attempts to strengthen environmental policy and few or no major changes to our environmental laws. And despite the initial optimism brought forth by the election of Barack Obama to change the status quo, few serious efforts have been made to make major changes to our national energy or environmental strategies (Kraft 20Ix)

Despite this less than optimistic outlook, it can be argued that environmentalism is now part of mainstream American life, with environmental groups at the national, state, and local levels playing an important role in a political system dominated by interest groups. To be sure, the environmental movement in the United States has "evolved into a mature and very typical American interest group community . . . one with an impressive array of policy niches and potential forms of activism” (Lee 1993, 34).

Furthermore, in spite of the highly publicized movement toward the internationalization of environmental issues-one that now embraces a global conception of environmental degradation (Rosenbaum 2014) and a new generation of environmental problems (Vig and Kraft 2013) - many of our nation's "old" environmental problems remain. Implementation of the Clean Air Act, cleanup of our federal nuclear waste facilities, and the question of opening up more public lands to oil exploration continue to be vital areas of public policy concern. In the United States, as elsewhere in the world, we are still coming to terms with such environmental problems as air and water pollution, hazardous materials, and the preservation of our public lands. As a nation, we have not been able to integrate policy, science, and the law into 
a coherent public policy strategy that deals with our environment. Nor have we been able to bring about a combination of creative new technologies, broad public participation, and appropriate behavioral changes to develop any type of comprehensive environmental or energy strategy. This is noteworthy today because of the increased visibility of energy issues, particularly in the context of the emotional debate regarding climate change (Kraft 20II).

Moreover, our environmental problems are inherently public problems, problems whose solutions must come from within the same complex and dynamic public policymaking process described earlier. In essence, environmental policymaking is subject to the direct and indirect influence of those features that make American politics unique. In this regard, American federalism lies at the core of many environmental issues. Who should be responsible for hazardous waste siting and nuclear waste cleanup? Who should have the most say in how our national forests are managed or preserved and whether Alaskan tundra should be opened for oil exploration? Who owns the rights to the precious water that flows through our western rivers? These questions can only be answered within a framework of intergovernmental cooperation and competition.

Environmental policy is fragmented in every sense of the word. Administrative agencies guard their turf with much resolve, leading more to competition than to cooperation. Judges overrule executives. Executives defy regulatory directives. Redundancy and overlap abound in attempts to control our environmental heritage. Policy is anything but consistent, and innovative change occurs rarely. No environmental policy is left unscathed by the intricacies of these American political characteristics. Whether the challenge comes from within the intergovernmental realm, through conflict between branches, from the pressures of interest groups, or simply with our bureaucratic infrastructure, the policy outcomes reflect the values of the American system.

The words of Dean Mann remain an accurate description of the unique and complex aspects of environmental policymaking in America: "That the politics of environmental policymaking is a process of dramatic advances, incomplete movement in the 'right' direction, frequent and partial retrogression, sometimes illogical and contradictory combinations of policies, and often excessive cost should come as no surprise to students of American politics. Environmental policies reflect the dominant structures and values of the American political system" (I986, 4). 
Thus, we are left with the task of evaluating our nation's environmental policy within the confines of an institutional structure that embodies a unique and often fractionalized political system. We are attempting to resolve age-old environmental problems as well as dealing with a third generation of environmental problems. In addition, we are left with the fact that solutions to environmental problems, in the absence of fundamental institutional or constitutional change, can only be resolved through the public policymaking process as it now stands.

\section{Tensions in the Environmental Policymaking World}

Having accepted the idea that environmental policymaking in the United States not only reflects the dominant values of the American political system but also follows the same policymaking process that guides other governmental issues, it is time to recognize that environmental policy is singularly unique in many aspects, notably because any change in policy requires substantial changes in the way we view the social and environmental aspects of such change (Kraft 20II). Several tensions exist in the world of environmental policymaking that set it apart from otherpolicy areas.

First, the prominence of the environmental ethos on the American agenda is a relatively new phenomenon, essentially beginning in the late I960s and catapulting to the forefront during the I970s (Vig and Kraft 2013). This relatively new interest in the environment has led to several sets of competing value systems, each attempting to preserve its way of life. The most obvious is represented by the conflict between the development of our natural resources and environmental protection (Kraft 20II).

At a philosophical level, this conflict reflects differences between American interests that place their highest value on economic growth and those that place their highest value on environmental protection (Rosenbaum 2014). The dominant American values of capitalism and the market system revolve around the belief that humans are the center of the universe and are responsible for the management of the world around them. This value system represents growth, development, and the use of technology to foster these ideals. Environmentalists, in contrast, share a much different viewpoint. In the words of Walter Rosenbaum, "Environmentalism sharply criticizes marketplace economics generally and capitalism particularly, and denigrates the 
growth ethic, unrestrained technological optimism, and the political structures supporting these cultural phenomena" (ibid., 50).

At a more practical level, this friction between values is apparent when examining the concept of environmental protection. American preoccupation with economic growth and resource management, developed early on in the American experience, has given way to a new set of concerns that include quality-of-life issues like the environment (Vig and Kraft 2013). Although degrees of conflict exist, people are now asked to choose between economic development and environmental protection. Pervading this decision choice are the questions of who should control our natural resources and which value should have a higher priority, economic growth or environmental protection. Policy debates over the construction of the Keystone pipeline from Alberta to Texas, the protection of old-growth forests in the Pacific Northwest, the opening of Alaska to oil exploration, the siting of a permanent nuclear waste facility in Nevada, and whether dams along the Snake and Columbia Rivers should be removed to enhance the return of salmon to their spawning grounds are all representative of the larger argument between growth and environmental protection, between conservation/management and preservation.

A subset of the friction between economic growth and environmental protection is easily seen within the continuing and current debate between environmental groups and property) rights advocates at the state and local levels (Bosso and Gruber 2006): This particular clash of values has been portrayed in the past by various Wise Use movements and is currently reflected by the numerous court cases involving regulatory takings and land use that are prevalent in today's western states (O'Leary 2006). Furthermore, this particular value clash will most likely be part of the environmental policy debate (especially in the West) well into the future.

Another tension revolves around the question of which method is most appropriate for carrying out environmental policy-government regulation or a market-oriented system. Part of the problem is that market systems "often pay little attention to the future values of natural resources and little if any attention to intrinsic values that are not measurable in monetary terms" (Smith 2009, 9). Conflicts arise over which method is more efficient and which one leads to greater environmental protection. With the seemingly endless increase in environmental problems (endangered species, hazardous waste 
disposal, global warming, fracking), some believe it is only through governmental control and regulation that we can meet the demand for increased environmental protection. However, others reject this argument and identify a critical need to supplement regulation with market-based incentives and collective decision making (Kraft 20II). An example of this tension is the policy gridlock that dominates the search for new energy supplies, with no consensus on how we should approach a national energy strategy from the US Congress, the president, or the public (Vig and Kraft 2013).

A current trend related to the tension between government regulation and market forces is the growing use of collaborative ecosystems management. As William Lowry points out, "Perhaps the most promising thirdstage proposals for resource policies are those that attempt collaborative, science-based resolutions to achieve innovative manàgement of natural ecosystems" $(2006,320)$. Examples of such collaborative processes are efforts to protect old-growth forest ecosystems, efforts to reconcile natural preservation and development interests, and adaptive management efforts to control the waters of the Colorado River (ibid.).

A further tension present in American environmental policymaking involves the science-policy linkage. Conventional wisdom posits that environmental questions are fundamentally questions of science. Walter Rosenbaum puts this very succinctly: What often distinguishes environmental policy making from other policy domains is the extraordinary importance of science, and scientific controyersy, in the policy process" $(2014,70)$. At the same time, there exists recognition that it is not easy to translate the findings of science into reasonable public policies. This tension between scientists and policymakers appears to be emblematic of all environmental policymaking.

One last point must be made with respect to the recent emergence of environmental protection as a major American value: it is here to stay. Environmental protection has not only been acknowledged as one of the oldest social issues (Sussman, Daynes, and West 2002) as well as part of a new paradigm of social values (Milbrath 1984), but it has been institutionalized into the American policymaking process. The establishment of the National Environmental Policy Act (NEPA, 1970), environmental impact statements (EISs), the Council on Environmental Quality (CEQ), and the Environmental Protection Agency (EPA) bear witness to this fact. There should be no doubt in anyone's mind that environmental protection is now considered one of the 
core values of American society, along with social justice, economic prosperity, national security, and democracy (Rosenbaum 20I4; Vig and Kraft 20I3).

\section{Western Environmental Policymaking}

Joel Garreau characterized the American West as a region blessed with a "spirit-lifting physical endowment" and as a repository for the "values, ideas, memories, and vistas that date back to the frontier" (198I, 302-3). The West continues to bask in a frontier image of mythic proportions (Hupp and Malachowsky 1993; Limerick 1987; Rudzitis 1996; Thompson 1998). It is characterized as having a wholly formed self-image defined by an idealistic and romantic western value system (Rothman 1999), where the "isolation, the struggle with nature, and the unpredictable opportunities fostered a resourcefulness, self-reliance, and spirit of working together" (Arrington 1994, 256).

This particular aspect of the western myth - the idea that it was rugged, self-reliant individualists who built the West-remains strong today. More important, this myth fits in nicely with a particular aspect of the Mountain West's political culture-the long-established resentment of eastern interference in the western way of life. To this way of thinking, the role of the federal government in creating the conditions and expending the capital that allowed the West to grow and flourish is simply ignored (Barker, Freemuth, and Johnson 2002).

For years, writers have described the feeling of western alienation from national politics and discontent with the eastern establishment. References are often made to a "sense of disadvantage, exploitation, and betrayal" that permeates the West (Bartlett 1993, III), as well as a "sense of helplessness bred of the perception that decisions in the West are made from the outside and that western communities have never been able to control their own destinies" (Wilkinson 1992, 30I). The words of former Idaho governor Cecil Andrus, referring to national media coverage of issues like the Endangered Species Act and forest fire prevention, reflect this sentiment: "There is a vastness west of the rooth meridian that you people don't understand. There is a culture out here that is different from Manhattan" (Andrus 2002, I).

Those from outside the West seem to have trouble understanding this particular point of view. For example, in his keynote address at a conference concerning the national media's relationship to public policy and the 
West, former ABC World News anchor Peter Jennings summed up his view of the West's particular brand of federalism: "I am somewhat puzzled at the tendency here in the West to be antigovernment and even to only reluctantly acknowledge that the federal government and western development are incontrovertibly together. Without the government, western development would have been so different . . An objective person would argue that it would have been a much poorer place without the federal government" (2002, 5I).

To understand why the West is truly unique in this regard requires us to look at only one statistic: the federal government owns nearly half of all the land area in the twelve westernmost states, including more than half of the land in Nevada (83.I\%), Alaska (67.9\%), Idaho (62.5\%), Utah (64.5\%), and Oregon (52.8) and nearly half of the land in Wyoming (49.9\%); more than one-third of the land in Arizona (45.6\%), California (44.9\%), Colorado $(36.4 \%)$, and New Mexico (34.2\%); and nearly one-third in Washington (28.5\%) and Montana (28.5\%) (Rosenbaum 2002, 308-9). This federal ownership has resulted in both an undue reliance and dependence on the federal government and a resentment of federal interference.

Critical decisions concerning the West's natural resources and lands have long been concentrated at the federal level. This control was greatly enhanced in the 1970s when Congress substantially increased its federal authority for developing and enforcing air and water-quality standards, committed the federal government to retain ownership and management of public lands, and consolidated federat responsibility for energy development and planning (Francis and Ganzel 1984). This followed a long historical relationship in which the federal government had been almost singularly responsible for the development of western natural resources through the establishment of water supplies, grazing fees, timber roads, and access to minerals. This conflict over control between the western states and the federal government has only been acerbated by the sustainability challenge of producing more energy at home (McNabb 2009) and the rhetoric describing global warming as one of several "catastrophic disasters" (Kline 20II, 192) pushing the federal government to take some kind of action.

But this heavy dependence on the federal government by the West has been defined as one of necessity, not choice (Francis and Thomas 199I). The Sagebrush Rebellion of the ra7os (a movement centered on the demand that 
federal lands in the West be turned over to the states in which they lay) and the County Supremacy/Wise Use movement of the I99os (a movement centered on the demand that counties should have joint sovereignty over federal lands within their borders) have come to symbolize the strong anti-government feelings in the West and the perceived federal interference into western values (Alm and Witt 1997; DeVine and Soden 1997; Layzer 2002). The tensions over property rights (described earlier) represent the same anti-government sentiments that pervade many western states today.

And these tensions are not going away anytime soon. The Obama administration cites extreme weather conditions as proof that federal action is needed to address global climate change (Taylor 2013) at the same time the Western Governors Association is calling for more independence from federal control and more cooperation from the White House and federal agencies so that states can meet their energy and environmental challenges (Roche 2013). The need for such cooperation is truly apparent today, as western states struggle with extreme drought conditions, out-of-control wildfires, and critical water shortages that only fuel the debate over climate-change policy (Carter and Culp 2010). Moreover, climate-change concerns highlight the water-energy nexus in the western states (Fisher and Ackerman 20II), as well as the need for clearer policies regarding nuclear energy (Austin 2013) and what part western states will play as a leader in energy development (Roche 2013). These energy and climate-change concerns are exacerbated in the West because eight of the ten states that account for almost all of the onshore oil reserves in the United States are located in the American West (Ausick and Sauter 2013).

Coupling these somber environmental and energy concerns with the frontier ethos of rugged individualism, anti-government sentiments, and a complex and contradictory set of intergovernmental relations makes the American West a very unique and interesting venue of study, for at no time can the influence and impact of the federal government be overlooked. Many policymakers in the West truly believe the national-level government has declared a war on the West and have responded with anti-tax, antiregulation, and anti-Washington rhetoric (Switzer 2004). Disputes over natural resources—-be they over fossil fuels (e.g., oil, natural gas, coal), nuclear energy, water, or minerals - remain at the center of the western landscape, mostly because of the sheer acreage of public lands in the West. As Michael Kraft points out: "These public lands and waters include awe-inspiring 
mountain ranges, vast structures of open desert, pristine forests, spectacular rivers and lakes, and the magnificent national parks ... They also contain valuable timber, minerals, energy resources, and water vital to irrigated crops in the West" (201I, I80).

Therein lies the problem and the paradox. So much of the West depends on these public lands and natural resources to drive the economy at the same time there is (mostly) a national cry to preserve these lands or keep them viable for recreational purposes. The West (overwhelmingly urban and suburban, with many of the fastest-growing states population-wise) is being transformed from an extractive resource-based economy to one reliant on communications, electronics, computer manufacturing, tourism, and retirees (ibid.). Hence, the conflict between resource development and environmental protection will continue to dominate public debates in this part of the United States.

\section{Conclusion}

The heart of American public policy falls within the realm of government attempting to solve and ameliorate socialproblems. Western environmental policymaking is no exception. It possesses the special policy characteristics that make the US system unique.Policy is dependent on institutional structures, political behavior, intergovernmental relations, and the myriad elements that symbolize the American policymaking system. Furthermore, the West feels the effects of decentralization, a dynamic and shifting population base, the increased pressure of global influences, and the increased concern for quality-of-life issues like environmental protection. However, within this policy structure, the West has witnessed a significant increase in intergovernmental and value conflicts. The concepts that embody American federalism have been severely tested in the West.

The single factor that dominates western environmental policymaking remains the high degree of influence, almost dominance, of the federal government. This is a direct result of the continued prominence of natural resources in western social, economic, and political life. Although there has been a substantial decline in dependence on a natural resource-based economy and an increased concern for quality-of-life issues, natural resources still define the texture of western environmental policymaking. As Norman 
Vig and Michael Kraft have pronounced, "The high level of political conflict over environmental protection efforts recently underscores the important role government plays in devising solutions to the nation's and [the] world's mounting environmental ills" $(2013,4)$.

The federal government owns over half of the West's land base and has historically played the major role in the development of the natural resources on these lands. While accepting the need for a federal presence in this development and enjoying the wealth that comes with royalties wrought from the extraction of resources, the West still has managed to foster a strong anti-government rhetoric against federal interference. Moreover, with the federal government recently taking the lead in enforcement of environmental regulations, both the federal presence and the anti-government sentiment have expanded in scope.

A quick survey of some of the key issues at the top of the policymaking agenda in the western states verifies the increased tension among intergovernmental participants. Witness the extended controversies surrounding the designation of wilderness area, the use of snowmobiles in Yellowstone National Park, the battle over water rights in the midst of a prolonged drought, the question of opening additional Alaskan land to oil exploration, and the reintroduction of wolves to the Mountain West. A common thread running through all these issues is the West's desire to play a greater role in deciding its own fate and controlling its own destiny.

While the environmental ethos has gained a strong foothold in some western states, the vast majority of those states remain grounded in their heritage-natural resource extraction from a vast, beautiful, and bountiful landscape. This foundation makes it impossible to study environmental policymaking in the West without considering both the imagery and the reality of the West as a place dominated by rugged individualism and reliance on the federal government. Simply put, the West is a place where federalism meets environmental policymaking head-on and where the battle for environmental supremacy remains tied to the opposing values of natural resource development and environmental protection. In the end, environmental policymaking in the American West is an accurate reflection of the chaotic, dynamic value structures that mark public policymaking in the United States. 


\section{References}

Adam, S., and H. Kriesi. 2007. “The Network Approach.” In Theories of the Policy Process, edited by P. Sabatier, I29-54. Boulder: Westview.

Alm, L., R. Burkhart, and M. Simon. 2010. Turmoil in American Public Policy: Science, Democracy, and the Environment. Santa Barbara, CA: Praeger.

Alm, L., and S. Witt. 1997. "County Governments and Public Lands: A Review of the County Supremacy Movement in Four Western States.” In Public Lands Management in the West, edited by B. Steel, 95-IIo. Westport, CT: Praeger.

Andrus, C. 2002. Dateline: The West. Official Transcripts. Boise State University: Andrus Center for Public Policy.

Arrington, L. I994. History of Idaho, vol. 2. Moscow: University of Idaho Press.

Ausick, P., and M. Sauter. 2013. "The io Most Oil-Rich States.” USA Today, August 3. Accessed August 15, 20I3. http: / / www.usatoday.com.

Austin, J. 20I3. "INL Cleanup to Resume in September." Idaho State Journal, June 28. Accessed June 28, 20I3. http:/ / www.idahostatejournal.com.

Baber, W., and R. Bartlett. 2009. Global Democracy and Sustainable Jurisprudence: Deliberative Environmental Law. Cambridge, MA: MIT Press.

Barker, R., J. Freemuth, and M. Johnson. 2002. Proceedings from the 2002 Andrus Conference: Dateline: The West. Boise, ID: Andrus Center for Public Policy.

Bartlett, R. 1993. "Political Culture and the Environmental Problematique in the American West." In Environmental Politics and Policy in the West, edited by Z. Smith, IOI-I6. Dubuque, IA: Kendall/Hunt.

Baumgartner, F., and B. Jones. 1993. Agendas and Instability in American Politics. Chicago: University of Chicago Press.

Bonser, C., E. McGregor, and C. Oster. 2000. American Public Policy Problems. Upper Saddle River, NJ: Prentice-Hall.

Bosso, C. 1987. Pesticides and Politics: The Life Cycle of a Public Issue. Pittsburgh: University of Pittsburgh Press.

Bosso, C., and D. Gruber, 2006. "Maintaining Presence: Environmental Advocacy and the Permanent Campaign." In Environmental Policy: New Directions for the Twenty-First Century, edited by N. Vig and M. Kraft, 78-99. Washington, DC: CQ Press.

Carter, R., and S. Culp. 20Io. Planning for Climate Change in the West. Cambridge, MA: Lincoln Institute of Land Policy.

Cochran, C., L. Mayer, T. R. Carr, and M. McKenzie. 2003. American Public Policy, 7 th ed. Belmont, CA: Wadsworth.

DeVine, K., and D. Soden. 1997. "Changing Political Geometry: Public Lands and Natural Resources in Nevada." In Public Lands Management in the West, edited by B. Steel, I29-50. Westport, CT: Praeger.

Fisher, J., and F. Ackerman. 20II. The Water-Energy Nexus in the Western States: Projections to 2010. Stockholm: Stockholm Environment Institute. 
Francis, J., and R. Ganzel. 1984. Western Public Lands: The Management of Natural Resources in a Time of Declining Federalism. Totowa, NJ: Rowman and Allanheld.

Francis, J., and C. Thomas. 1991. "Influences on Western Political Culture." In Politics and Public Policy in the Contemporary American West, edited by C. Thomas, 23-53. Albuquerque: University of New Mexico Press.

Garreau, J. 198I. The Nine Nations of North America. Boston: Houghton Mifflin.

Gerston, L. 2008. Public Policymaking in a Democratic Society: A Guide to Civic Engagement, and ed. New York: M. E. Sharpe.

Hofferbert, R. 1974. The Study of Public Policy. Indianapolis: Bobbs-Merrill.

Hupp, D., and J. Malachowsky. 1993. "The Politics of Polarization: Rural Divide." Western States Center News Io: I-8.

Ingram, H., A. Schneider, and P. de Leon. 2007. "Social Construction and Policy Design.” In Theories of the Policy Process, edited by P. Sabatier, 93-I26. Boulder: Westview.

Jennings, P. 2002. "Dateline: The West.” Boise, ID: Andrus Center for Public Policy. December 6.

John, P. 2003. "Is There Life after Policy Streams, Advocacy Coalitions, and Punctuations: Using Evolutionary Theory to Explain Policy Change?" Policy Studies Journal: The Journal of the Policy Studies Organization 3I (4): 48I-98. http:// dx.doi .org/IO.IIII/ I54I-0072.00039.

Kettle, D. 2012. The Politics of the Administrative Process, 5th ed. Los Angeles: Sage.

Kingdon, J. 20Ir. Agendas, Alternatives, and Public Policies. Updated, 2nd ed. New York: HarperCollins.

Kiser, L., and E. Ostrom. 1982. “The Three Worlds of Action.” In Strategies of Political Inquiry, edited by E. Ostrom, I79-222. Beverly Hills: Sage.

Kline, B. 20II. First along the River: A Brief History of the U.S. Environmental Movement, 3rd ed. New York: Rowman and Littlefield.

Kraft, M. 20Ir. Environmental Policy and Politics, 5 th ed. Boston: Longman.

Kraft, M., and S. Furlong. 2013. Public Policy: Politics, Analysis, and Alternatives. Los Angeles: Sage and CQ Press.

Layzer, J. 2002. The Environmental Case: Translating Values into Policy. Washington, DC: CQ Press.

Lee, K. N. 1993. Compass and Gyroscope: Integrating Science and Politics for the Environment. Washington, DC: Island.

Limerick, P. 1987. The Legacy of Conquest: The Unbroken Past of the American West. New York: W. W. Norton.

Lowry, W. 2006. "A Return to Traditional Priorities in Natural Resource Policies." In Environmental Policy: New Directions for the Twenty-First Century, edited by N. Vig and M. Kraft, 3II-32. Washington, DC: CQ Press.

Mann, D. 1986. "Democratic Politics and Environmental Policy." In Controversies in Environmental Policy, edited by S. Kamieniecki, R. O’Brien, and M. Clarke, 3-34. Albany: University of New York Press. 
McNabb, D. 2009. The New Face of Government: How Public Managers Are Forging a New Approach to Governance. New York: CRC Press.

Milakovich, M., and G. Gordon. 2013. Public Administration in America, IIth ed. Boston: Wadsworth.

Milbrath, L. I984. Environmentalists: Vanguard for a New Society. Albany: State University of New York Press.

O’Leary, R. 2006. "Environmental Policy in the Courts." In Environmental Policy: New Directions for the Twenty-First Century, edited by N. Vig and M. Kraft, I48-68. Washington, DC: CQ Press.

Ostrom, E. 1990. Governing the Commons: The Evolution of Institutions for Collective Action. New York: Cambridge University Press. http: / / dx.doi.org/Io.IoI7/CBO 9780511807763.

Ostrom, E. 1999. "Institutional Rational Choice: An Assessment of the Institutional Analysis and Development Framework." In Theories of the Policy Process, edited by P. A. Sabatier, 35-72. Boulder: Westview.

Ostrom, E. 2007. "Institutional Rational Choice: An Assessment of the Institutional Analysis and Development Framework." In Theories of the Policy Process, edited by P. Sabatier, 2I-64. Boulder: Westview.

Robertson, D., and D. Judd. 1989. The Development of American Public Policy: The Structure of Policy Restraint. Glenview, LL: Scott, Foresman.

Roche, L. 2013. "Western Governors Explore Future of Region's Role as Leader in Energy Development.” June 30. Accessed September 23, 2013. http: / / deseret news.com.

Rosenbaum, W. 2002. Environmental Politics and Policy, 5th ed. Washington, DC: CQ Press.

Rosenbaum, W. 20I4. Environmental Politics and Policy, 9th ed. Washington, DC: CQ Press.

Rothman, H. 1999. "Tourism as Colonial Economy." In Power and Place in the North American West, edited by R. White and J. Findlay, 24-30. Seattle: University of Washington Press.

Rudzitis, G. 1996. Wilderness and the Changing American West. New York: John Wiley and Sons.

Sabatier, P. 2007. “The Need for Better Theories." In Theories of the Policy Process, edited by P. Sabatier, I-I7. Boulder: Westview.

Sabatier, P., and H. Jenkins-Smith. 1993. Policy Change and Learning. Boulder: Westview.

Sabatier, P., and C. Weible. 2007. "The Advocacy Coalition Framework: Innovations and Clarifications." In Theories of the Policy Process, edited by P. Sabatier, I89-220. Boulder: Westview.

Schneider, A., and H. Ingram. 1997. Policy Design for Democracy. Lawrence: University of Kansas Press.

Smith, Z. 2009. The Environmental Paradox, 5th ed. Upper Saddle River, NJ: Pearson/ Prentice-Hall. 
Stone, D. 20I2. Policy Paradox: The Art of Political Decision Making, 3rd ed. New York: W. W. Norton.

Sussman, G., B. Daynes, and J. West. 2002. American Politics and the Environment. New York: Longman.

Switzer, J. 2004. Environmental Politics: Domestic and Global Dimensions, 4th ed. Belmont, CA: Thomson/Wadsworth.

Taylor, P. 20I3. "EPA Has 'Moral Obligation' to Act on Global Warming." August I4. Accessed September 23, 20I3. http: / / www.eenews.net.

Thompson, J. 1998. Forging the Prairie West: The Illustrated History of Canada. Toronto: Oxford University Press.

True, J., B. Jones, and F. Baumgartner. 2007. "Explaining Stability and Change in Public Policymaking." In Theories of the Policy Process, edited by P. Sabatier, I55-88. Boulder: Westview.

Vig, N., and M. Kraft. 2013. Environmental Policy: New Directions for the 21st Century, 8th ed. Los Angeles: Sage.

Weschler, L. 1991. “Taming the Common Pool." Joumal of Public Administration Research and Theory: J-PART I (4): 488-92.

Wilkinson, C. 1992. The Eagle Bird: Mapping a New West. New York: Vintage Books. Zahariadis, N. 2007. "The Multiple Streams Framework: Structure, Limitations, Prospects." In Theories of the Policy Process, edited by P. Sabatier, 65-92. Boulder: Westview. 